\title{
Actions of putative embryokines on development of the preimplantation bovine embryo to the blastocyst stage
}

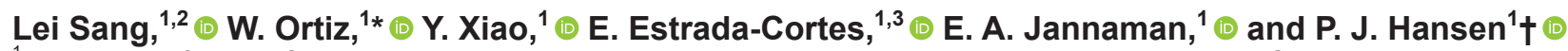 \\ ${ }^{1}$ Department of Animal Sciences, D. H. Barron Reproductive and Perinatal Biology Research Program, and Genetics Institute, \\ University of Florida, Gainesville 32611-0910 \\ ${ }^{2}$ Institute of Animal Husbandry and Veterinary Medicine, Fujian Academy of Agricultural Sciences, Fuzhou, Fujian, 350013, China \\ ${ }^{3}$ Campo Experimental Centro Altos de Jalisco, Instituto Nacional de Investigaciones Forestales, Agrícolas y Pecuarias, Tepatitlán de Morelos, \\ Jalisco, México 47600
}

\section{ABSTRACT}

Once it enters the uterus at d 4 to 5 after ovulation, the preimplantation bovine embryo is controlled in its development by regulatory signaling molecules from the mother called embryokines. Here, several cell-signaling molecules whose genes are expressed in the endometrium during d 5 to 7 after estrus were tested for the ability to affect the competence of the embryo for further development and the characteristics of the resultant blastocysts. Molecules tested were Cnatriuretic peptide (CNP), IL-8, bovine morphogenetic protein 4 (BMP-4), IL-6, and leukemia inhibitory factor (LIF). None of the cell-signaling molecules tested improved the competence of the embryo to become a blastocyst; in fact, BMP-4 decreased development. All molecules modified attributes of the blastocyst formed in culture. In particular, CNP increased the number of cells in the ICM, whereas IL-8 decreased inner cell mass cell numbers and tended to increase the proportion of blastocysts that were hatching or hatched. In addition, BMP-4 decreased the proportion of blastocysts that were hatching. Interleukin-6 and, to a lesser extent, LIF activated the Janus kinase (JAK)/signal transducer and activator of transcription 3 (STAT3) signaling pathway in the inner cell mass, and LIF increased the percent of cells in the blastocyst that were positive for both NANOG and phosphorylated (activated) STAT3. In conclusion, our results indicate that CNP, IL-8, IL-6, LIF, and BMP-4 can modify embryonic development of the cow in a manner that affects characteristics of the resultant blastocyst. Further research is required to understand how these changes in characteristics of the

Received June 10, 2020.

Accepted July 29, 2020.

*Current address: Departamento de Nutrição Animal do Grupo Matsuda, Rodovia Raposo Tavares, SP 270, Km 575, Álvares Machado - SP, Brazil.

†Corresponding author: pjhansen@ufl.edu blastocyst would affect competence of the embryo to establish and maintain pregnancy.

Key words: embryokine, embryo, blastocyst, pregnancy

\section{INTRODUCTION}

Successful pregnancy requires interactions between the reproductive tract and the developing embryo. In cattle, the embryo alters endometrial function as early as d 7 of gestation (Sponchiado et al., 2017). The maternal environment is important for appropriate embryonic development because embryos produced in vitro differ in many biochemical, molecular, and ultrastructural characteristics from embryos developing in vivo (Hansen, 2020) and are less able to establish pregnancy after transfer than embryos produced in vivo (Ealy et al., 2019). Moreover, addition of specific molecules produced by the endometrium to cultured embryos can modify the characteristics of embryonic development. These molecules have been termed "embryokines" because they regulate development of the preimplantation embryo.

Some embryokines such as colony-stimulating factor 2 (CSF2; Loureiro et al., 2009; Denicol et al., 2014), IGF1 (Block and Hansen, 2007) and dickkopf 1 (DKK1; Denicol et al., 2014) can increase competence of embryos to establish pregnancy after transfer into recipients. Other embryokines in the cow have been identified that can either increase the percent of embryos that develop to the blastocyst stage in vitro or alter characteristics of the resultant blastocysts. Among these are activin A (Kannampuzha-Francis et al., 2017; Tríbulo et al., 2018a), connective tissue growth factor (CTGF; Kannampuzha-Francis et al., 2017), IL-6 (Wooldridge et al., 2019; Wooldridge and Ealy, 2019), fibroblast growth factor 2 (Fields et al., 2011), hepatoma-derived growth factor (HDGF), and WNT7A (Tríbulo et al., 2017, 2018a). Actions of one embryokine, CSF2, are different for male embryos than for female embryos (Dobbs et 
al., 2014; Siqueira and Hansen, 2016), whereas actions of others, such as activin A, IGF-1, and WNT7A, appear similar for embryos of both sexes (Tríbulo et al., 2018a).

The bovine embryo first enters the uterus at d 4 or 5 after estrus (Hackett et al., 1993). At this time, the endometrium expresses a large number of genes that encode for hormones, growth factors, chemokines, cytokines, and WNT-related molecules (Tríbulo et al., 2018b). Similarly, many of the metabolites present in uterine fluid participate in cell signaling (Tríbulo et al., 2019a). Conditions associated with fertility, such as the endocrine environment at proestrus (Mesquita et al., 2015; Sá Filho et al., 2017) and progesterone secretion early in the estrous cycle (Forde et al., 2011), are associated with altered expression of specific cell signaling genes at d 6 to 7 after ovulation. Nonetheless, the role of most uterine cell-signaling molecules in embryonic development is still not known. Identification of molecules produced by the endometrium that function as embryokines could lead to improvements in culture systems for bovine embryos and may result in new approaches to improving cow fertility based on increasing concentrations of embryotrophic molecules in the uterus.

Here we evaluated several cell-signaling molecules for their actions on development of the bovine embryo, including C-natriuretic peptide (CNP), encoded by natriuretic peptide precursor $\mathrm{C}$ gene (NPPC), IL-8, also known as C-X-C motif chemokine ligand 8 (CXCL8), bovine morphogenetic protein 4 (BMP-4), IL-6, and leukemia inhibitory factor (LIF). The genes for each of these molecules are expressed in the endometrium at Day 5 and 7 after estrus (Forde et al., 2011; Oliveira et al., 2013; Sá Filho et al., 2017; Moran et al., 2017; Tríbulo et al., 2018b). C-Natriuretic peptide is also present in bull seminal plasma (Chrisman et al., 1993) and could conceivably be one of the mediators of seminal plasma effects on the endometrium or embryo (Bromfield, 2018). Interleukin-8 is one of the cytokines whose expression can be upregulated in females experiencing uterine inflammation or infectious disease (Fagundes et al., 2019; Helfrich et al., 2020) as well as exposure to sperm (Akthar et al., 2020). The primary objective of the current experiments was to evaluate actions of these molecules to increase the capacity of the bovine embryo to develop to the blastocyst stage. In addition, other aspects of the blastocysts formed were evaluated, including, depending on the molecule, stage of blastocyst development (i.e., whether the blastocyst had initiated hatching), blastocyst total cell number, and allocation of cells to the inner cell mass (ICM) and trophectoderm (TE). Treatments were either added after fertilization or at d 4 of development, which is when the embryo first transits from the oviduct to the uterus (Hackett et al., 1993).

\section{MATERIALS AND METHODS}

\section{Embryo Production and Culture}

Procedures for embryo production are described in detail elsewhere (Tríbulo et al., 2019b). Briefly, cumulus-oocyte complexes (COC) were recovered from ovaries from cattle of undetermined breeds obtained from an abattoir. The COC were matured in groups of 10 in $50-\mu \mathrm{L}$ microdrops containing either a custom-made oocyte maturation medium for experiments $1,2,3$, and 7 , or a proprietary commercial oocyte maturation medium (IVF-Bioscience, Falmouth, Cornwall, UK) for experiments 4,5 , and 6 . The custom-made maturation medium consisted of TCM-199 containing 10\% (vol/ vol) fetal bovine serum, $0.2 \mathrm{~m} M$ sodium pyruvate, 2 $\mathrm{m} M$ alanyl-glutamine, $50 \mathrm{ng} / \mathrm{mL}$ recombinant human epidermal growth factor, $5 \mu \mathrm{g} / \mathrm{mL}$ follicle stimulating hormone (Folltropin-V, Vetoquinol, Fort Worth, TX), $100 \mathrm{U} / \mathrm{mL}$ penicillin, and $0.1 \mathrm{mg} / \mathrm{mL}$ streptomycin. Ingredients other than Folltropin- $\mathrm{V}$ were from ThermoFisher (Waltham, MA). Maturation drops were covered with mineral oil (Sigma Aldrich, St. Louis, MO) and incubated for 22 to $24 \mathrm{~h}$ at $38.5^{\circ} \mathrm{C}$ and $5 \%$ ( $\mathrm{vol} / \mathrm{vol}$ ) $\mathrm{CO}_{2}$ in a humidified atmosphere.

Matured COC were washed 3 times in HEPESbuffered Tyrode's albumin-lactate-pyruvate (HEPESTALP). Except for experiment 2, groups of up to 300 COC were fertilized in a plate containing $1700 \mu \mathrm{L}$ of in vitro fertilization Tyrode's albumin-lactate-pyruvate (IVF-TALP). Oocytes from each replicate (i.e., a group of COC collected on a single day) were fertilized using a pool of conventional spermatozoa from 3 sires of various breeds. Pools of bulls usually differed between replicates. Frozen semen was thawed and purified using a PureSperm 40/80 gradient (Nidacon International AB, Mölndal, Sweden). Each fertilization plate included $120 \mu \mathrm{L}$ of spermatozoa in IVF-TALP and $80 \mu \mathrm{L}$ of a solution containing $0.5 \mathrm{mM}$ penicillamine, $0.25 \mathrm{~m} M$ hypotaurine, and $25 \mu M$ epinephrine so that the final volume in the fertilization plate was $1,900 \mu \mathrm{L}$ and the final concentration of spermatozoa was $1 \times 10^{6} / \mathrm{mL}$. Fertilization plates were incubated for 12 to $22 \mathrm{~h}$ at $38.5^{\circ} \mathrm{C}$ and $5 \%$ (vol/vol) $\mathrm{CO}_{2}$ in a humidified atmosphere. For experiment 2, X-sorted semen was used. Sperm from a single bull was used for a specific replicate and a total of 3 bulls were used in the experiment. Procedures for fertilization were as described by Jannaman et al. (2020). Co-incubation of sperm and COC for fertilization was carried out for 19 to $22 \mathrm{~h}$ in oil-covered microdrops that included up to 30 
COC in $60 \mu \mathrm{L}$ of fertilization medium, $20 \mu \mathrm{L}$ of PureSperm-purified spermatozoa (final concentration of 1 $\times 10^{6} / \mathrm{mL}$ in IVF-TALP), $3.5 \mu \mathrm{L}$ of the penicillaminehypotaurine-epinephrine solution, and with amikacin (Sigma-Aldrich) added to a final concentration of 20 $\mu \mathrm{g} / \mathrm{mL}$.

Following fertilization and removal of cumulus cells by vortexing, presumptive zygotes (i.e., oocytes exposed to sperm) were placed in groups of 25 to 30 in $50-\mu \mathrm{L}$ microdrops of culture medium (synthetic oviduct fluid-bovine embryo 2, SOF-BE2) covered with mineral oil. Culture medium contained various treatments as described for each experiment. The vehicle or $0 \mathrm{ng} /$ $\mathrm{mL}$ group represented embryos cultured in SOF-BE2 containing a similar volume of vehicle diluted with culture medium equivalent to the dilution needed to prepare test substances. All culture drops were designed to contain the same final concentration of vehicle. Except for experiment 2, test substances were dissolved in Dulbecco's PBS (Sigma-Aldrich) containing $1 \mathrm{mg} /$ mL Fraction V BSA (DPBS/BSA; Sigma-Aldrich) and then further diluted in SOF-BE2 culture medium before addition to culture drops. For experiment 2, the original vehicle for all treatments was $10 \mathrm{~m} M$ citrate, $\mathrm{pH}$ 3.0, because BMP-4 required this buffer. This material was diluted 10-fold with DPBS/BSA and then diluted further in SOF-BE2 culture medium. Microdrops were incubated at $38.5^{\circ} \mathrm{C}$ in a humidified atmosphere of $5 \%$ $\mathrm{CO}_{2}$ (vol/vol), $5 \% \mathrm{O}_{2}$ (vol/vol), and $90 \% \mathrm{~N}_{2}$ (vol/vol). The percent of embryos that cleaved after insemination was evaluated at d 3 or 4 after insemination and the percent of embryos becoming blastocysts was evaluated at $\mathrm{d} 7.5$.

\section{Stage-Dependent Actions of CNP on Development of Embryos to the Blastocyst Stage (Experiment 1)}

The purpose was to determine whether CNP, added either from d 0 to 4,4 to 7.5 , or throughout the first 7.5 $\mathrm{d}$ of culture would increase the percent of presumptive embryos becoming blastocysts and alter blastocyst cell number. The design of the experiment was a $2 \times 2$ factorial with main effects of time of treatment (d 0 to 4 or $\mathrm{d} 4$ to 7.5 ) and CNP (0 or $200 \mathrm{nM}$ ). The human CNP was obtained from Sigma-Aldrich. The concentration of CNP tested was chosen because $200 \mathrm{n} M$ CNP can prevent resumption of meiosis in oocytes (Xi et al., 2018; Soto-Heras et al., 2019). After fertilization, embryos were placed in drops of SOF-BE2 containing vehicle or $200 \mathrm{n} M$ CNP. Cleavage was assessed in d 4 embryos. Embryos were then placed in fresh drops of SOF-BE2 containing either vehicle or $200 \mathrm{n} M$ CNP. Development to the blastocyst stage was assessed at $\mathrm{d}$ 7.5 after insemination. All blastocysts were harvested and analyzed for number of total cells, TE cells, and ICM cells as described below. The experiment was replicated 10 times with a total of 645 to 670 presumptive zygotes per group. The number of blastocysts analyzed for cell number was 31 to 48 per group.

Blastocysts were labeled with Hoechst 33342 (SigmaAldrich) to estimate blastocyst cell number and labeled with an antibody against caudal type homeobox 2 (CDX2, a TE marker) to estimate the number of TE and ICM cells. Blastocysts were washed 3 times in DPBS containing $0.1 \%$ (wt/vol) polyvinylpyrrolidone (DPBS/PVP; Kodak, Rochester, NY) and fixed in $4 \%$ (wt/vol) paraformaldehyde in DPBS/PVP for 15 min at room temperature. Thereafter, blastocysts were washed 3 times and stored for 2 to $3 \mathrm{~d}$ in DPBS/PVP at $4^{\circ} \mathrm{C}$ until the immunolabeling procedure. They were then incubated for $1 \mathrm{~h}$ at room temperature in 50$\mu \mathrm{L}$ drops of a blocking solution $[5 \%$ (wt/vol) BSA in DPBS/PVP], washed 3 times and incubated overnight at $4^{\circ} \mathrm{C}$ in $50-\mu \mathrm{L}$ drops containing $1 \mu \mathrm{g} / \mathrm{mL}$ antibody against CDX2 (affinity purified mouse monoclonal antibody against CDX-2, ready to use solution; BioGenex, Fremont, CA). For each procedure, one blastocyst was used as a negative control as described above. Blastocysts were washed 3 times and incubated for $1 \mathrm{~h}$ in $50-\mu \mathrm{L}$ drops containing $2 \mu \mathrm{g} / \mathrm{mL}$ secondary antibody (Alexa Fluor goat anti-mouse 488; ThermoFisher) diluted in DPBS/PVA containing 5\% (wt/vol) BSA. Subsequently, blastocysts were washed 3 times, incubated for $15 \mathrm{~min}$ at room temperature in $50-\mu \mathrm{L}$ drops containing $1 \mu \mathrm{g} / \mathrm{mL}$ Hoechst 33342, mounted on slides, and examined using an inverted microscope (AXIO observer Z.1, Zeiss, White Plains, NY) with an Andor DSD2 spinning disc confocal unit (Oxford Instruments, Abingdon, UK), a Plan Apochromat 20×/0.8 M27 WD $=0.55 \mathrm{~mm}$ objective, and a CoolLED pE4000 16 wavelength LED light source. Z-stack images of each blastocyst were acquired using a Zyla 4.2 Megapixel PLUS cMOS camera (Oxford Instruments) and Andor ZQ3 software. The multiple point tool of ImageJ (version 1.60_41; National Institutes of Health, Bethesda, MD) was used to count cells. Blastocyst cell number was estimated as the number of nuclei labeled with Hoechst 33342 , TE cell number was estimated as the number of nuclei labeled with CDX2, and the number of cells in the ICM was estimated as the difference between blastocyst cell number and TE cell number.

\section{Actions of CNP, BMP-4, and IL-8 on Development of Embryos Produced with X-Sorted Semen to the Blastocyst Stage (Experiment 2)}

We observed no effects of CNP on development to the blastocyst stage in experiment 1 . One possible 
reason might be that CNP has effects that depend upon embryo sex; if so, treating embryos of both sexes together could obscure an effect occurring in one sex. Accordingly, experiment 2 was conducted with embryos produced with X-sorted semen to evaluate effects of CNP in female embryos. Two other putative embryokines, BMP-4 and IL-8, were also examined. In particular, embryos were cultured with either vehicle, 200 $\mathrm{n} M$ CNP, $100 \mathrm{ng} / \mathrm{mL}$ recombinant human BMP-4 (Reprotech, Rocky Hill, NJ), or $100 \mathrm{ng} / \mathrm{mL}$ recombinant bovine IL-8 (Kingfisher Biotech, St. Paul, MN) from d 0 to 7.5 of development. The concentration of BMP-4 tested was shown previously to inhibit development of bovine embryos to the blastocyst stage (La Rosa et al., 2011). The concentration of IL-8 tested was chosen based on previous effects of IL- 8 on migration of mouse endothelial cells (Kimura et al., 2011) and proliferation and migration of mouse smooth muscle cells (Qin et al., 2013). Treatments were added at the end of fertilization when presumptive zygotes were placed in culture. Cleavage was assessed at $\mathrm{d} 3$ after insemination and the number of blastocysts was determined at d 7.5 after insemination. Blastocysts were also classified based on morphological stage of development as early, normal, expanded, hatching, or hatched. The experiment was replicated 8 times with 589 to 630 presumptive zygotes per treatment. The number of blastocysts per treatment ranged from 77 to 114 .

\section{Concentration-Dependent Actions of IL-8 on Development to the Blastocyst Stage (Experiment 3)}

Embryos were cultured with 0, 1, 10, or $100 \mathrm{ng} / \mathrm{mL}$ recombinant bovine IL- 8 from d 0 to 7.5 of development. Treatments were added at the end of fertilization when presumptive zygotes were placed in culture. Cleavage was assessed at $\mathrm{d} 3$ after insemination, and the number of resultant blastocysts was determined at d 7.5 after insemination. All blastocysts were harvested and analyzed for number of total cells, TE cells, and ICM cells as described for experiment 1 . The experiment was replicated 4 times with a total of 220 to 286 presumptive zygotes per group. The number of blastocysts analyzed for cell number was 33 to 44 per group.

\section{Concentration- and Time-Dependent Actions of IL-6 on Development to the Blastocyst Stage (Experiments 4-6)}

Three experiments were performed to evaluate whether IL-6 would alter competence of embryos to develop to the blastocyst state. Each experiment used recombinant bovine IL-6 from Kingfisher Biotech. For experiment 4 , embryos were cultured with $0,0.5,5$, or $50 \mathrm{ng} / \mathrm{mL}$ recombinant bovine IL-6 from d 0 to 7.5 of development. The IL- 6 treatments were added at the end of fertilization when presumptive zygotes were placed in culture. Cleavage was assessed at $\mathrm{d} 3$ after insemination and the number of blastocysts was determined at $\mathrm{d} 7.5$ after insemination. The experiment was replicated 8 times with a total of 299 to 307 presumptive zygotes embryos per group. For experiment 5 , embryos were treated from d 0 to 4 after insemination with $0,0.5,5$, or $50 \mathrm{ng} / \mathrm{mL}$ IL-6. At d 4, cleavage was evaluated, and embryos were then placed in fresh drops of medium without IL-6. Development to the blastocyst stage was assessed at $\mathrm{d} 7.5$ after insemination. The experiment was replicated 6 times with a total of 341 to 370 presumptive zygotes per group. For experiment 6 , embryos were cultured in SOF-BE2 from d 0 to 4 after insemination. Cleavage was determined at $\mathrm{d} 4$ and embryos were placed in fresh medium containing $0,0.5$, 5 , or $50 \mathrm{ng} / \mathrm{mL}$ IL-6. Culture proceeded until d 7.5 when blastocysts were counted. The experiment was replicated 7 times with a total of 466 to 481 presumptive zygotes per group.

\section{Actions of IL-6 and LIF to Activate STAT3 Signaling and Regulate Number of Total and NANOG-Positive Cells in the Blastocyst (Experiment 7)}

Recombinant bovine IL-6 and LIF were purchased from Kingfisher. Treatments, which were added at $\mathrm{d}$ 4 after insemination, were vehicle, $100 \mathrm{ng} / \mathrm{mL}$ IL-6, or $100 \mathrm{ng} / \mathrm{mL}$ LIF. Cleavage was assessed at d 4 after insemination and the number of blastocysts was determined at $\mathrm{d} 7.5$ after insemination. The experiment was replicated 6 times for a total of 357 to 373 presumptive zygotes.

Blastocysts at Day 7.5 were selected for immunolabeling regardless of developmental stage and processed for immunolabeling. All blastocysts were labeled using antibody against phosphorylated (p)STAT3 ( $\mathrm{n}=$ 56-57 blastocysts/group). For a subset $(\mathrm{n}=44-50$ blastocysts/group), blastocysts were also labeled using antibody against NANOG. Blastocysts were fixed in $4 \%$ (wt/vol) paraformaldehyde in DPBS/PVP for $15 \mathrm{~min}$ and permeabilized in ice-cold methanol for 10 min at $-20^{\circ} \mathrm{C}$. Blastocysts were then rinsed in DPBS/ PVP and blocked for $1 \mathrm{~h}$ at room temperature with $5 \%$ (wt/vol) BSA in DPBS/PVP. Blastocysts were then incubated overnight at $4^{\circ} \mathrm{C}$ with one or both primary antibodies diluted with antibody buffer [DPBS containing $0.3 \%$ (wt/vol) Triton X-100 and $1 \%$ (wt/vol) BSA]. The rabbit IgG monoclonal antibody against pSTAT3 
was designed for the residues surrounding Tyr705 of mouse STAT3 (9145S, Cell Signaling Technology, Danvers, MA) and was diluted 1:100 (vol/vol). The mouse $\mathrm{IgG}_{1} \kappa$ monoclonal antibody against human NANOG (14-5768-80, ThermoFisher) was used at $1.7 \mu \mathrm{g} / \mathrm{mL}$. After incubation, blastocysts were rinsed in DPBS/ PVP and then incubated with $10 \mu \mathrm{g} / \mathrm{mL}$ Hoechst 33342 and 1 or 2 secondary antibodies diluted in antibody buffer for $1 \mathrm{~h}$ at room temperature. Secondary antibodies were each diluted to $2 \mu \mathrm{g} / \mathrm{mL}$. The secondary antibody for pSTAT3 was goat anti-rabbit IgG coupled to Alexa Fluor 555 (A21428, ThermoFisher), and the secondary antibody for NANOG was goat anti-mouse IgG Alexa-647 (A21236, ThermoFisher). Both secondary antibodies had been absorbed to remove reactivity against immunoglobulins from other species.

Blastocysts were examined for immunofluorescence using an inverted microscope with an Andor DSD2 spinning disc confocal unit as described above. Z-stack images of each blastocyst were acquired using a Zyla 4.2 MP PLUS cMOS camera (Oxford Instruments) and Andor ZQ3 software. The multiple point tool of ImageJ was used to manually count cells. Additionally, intensity of nuclear labeling for pSTAT3 and NANOG for cells positive for those markers was quantified using ImageJ. For each embryo, z-stacks were first duplicated to create 2 files termed $\mathrm{A}$ and $\mathrm{B}$. In addition, intensity of nuclear labeling for pSTAT3 and NANOG for cells positive for those markers was quantified using ImageJ. Maximum projections of the stack of images were created separately for pSTAT3 and NANOG and background subtraction and Gaussian Blur tools were used to identify boundaries of positive nuclei. Intensity of the selected nuclei was calculated and corrected by subtracting background fluorescence.

\section{Statistical Analysis}

Data on the percent of embryos that cleaved after insemination and the percent of cleaved embryos that developed to the blastocyst stage were analyzed by logistic regression fitted to a binomial distribution using the GLIMMIX procedure of SAS software, version 9.4 (SAS Institute Inc., Cary, NC). Models included various fixed effects of treatment and random effect of replicate. Data on cell number and intensity of labeling for pSTAT3 and NANOG were analyzed by ANOVA using the GLM procedure of SAS using effects of treatment in the mathematical model. For both type of analyses, the contrast statement was used to determine groups that differed significantly from the vehicle control (i.e., $0 \mathrm{ng} / \mathrm{mL})$.

\section{RESULTS}

\section{Stage-Dependent Actions of CNP on Development of Embryos to the Blastocyst Stage (Experiment 1)}

There was no effect of CNP on cleavage (results not shown) or on the percent of presumptive zygotes that developed to the blastocyst stage (Figure 1A). This was true whether CNP was added from Day 0 to 4,4 to 7.5, or 0 to 7.5. There was also no effect of CNP on blastocyst total cell number (Figure 1B) or number of TE cells (Figure 1C). In contrast, blastocysts cultured with CNP from Day 4 to 7.5 or from Day 0 to 7.5 had more ICM cells than blastocysts cultured without CNP (Figure 1D).

\section{Actions of CNP, BMP-4, and IL-8 on Development of Embryos Produced with X-Sorted Semen to the Blastocyst Stage (Experiment 2)}

This experiment was performed with X-sorted semen to reduce variation due to sex and because, at least for CSF2 (Siqueira and Hansen, 2016), female embryos are more sensitive to development-modifying actions of embryokines. Results are shown in Figure 2. Initial analyses, comparing each cell-signaling molecule to the vehicle control, did not result in any significant effect of CNP, BMP-4, or IL-8 on any endpoint, although there was a tendency $(P=0.0686)$ for the percent of blastocysts that were hatched or hatching to be lower for blastocysts treated with BMP-4 (Figure 2D). When data were reanalyzed comparing BMP-4 with the other treatments (vehicle, CNP, and IL-8), we found that BMP-4 caused a slight reduction $(P=0.0345)$ in the number of COC that cleaved and in the percent of presumptive zygotes that became blastocysts $(P=0.0428)$. The reduction in the latter endpoint was largely the result of the lower cleavage rate in the BMP-4 group, because there was no significant effect of BMP-4 on the percent of cleaved embryos becoming blastocysts $(P=0.1080)$. Treatment with BMP-4 did, however, reduce the percent of blastocysts that were hatching or hatched $(P=0.0264)$.

\section{Concentration-Dependent Actions of IL-8 on Development to the Blastocyst Stage (Experiment 3)}

Culture of embryos from Day 0 to 7.5 with 1,10 , or $100 \mathrm{ng} / \mathrm{mL}$ IL-8 had no effect on cleavage (not shown), percent of presumptive zygotes becoming blastocysts (Figure 3A), percent of blastocysts at Day 7.5 that 
were hatching or hatched (Figure 3B), total cell number (Figure 3C), or TE cell number of blastocysts (Figure 3D). There was, however, a negative effect of $100 \mathrm{ng} /$ $\mathrm{mL}$ IL-8 on the number of ICM cells in blastocysts (Figure 3E).

\section{Concentration- and Time-Dependent Actions of IL-6 on Development to the Blastocyst Stage (Experiments 4-6)}

We observed no effect of IL-6 on the percent of presumptive zygotes that cleaved in any experiment (results not shown). Results on development of presump- tive embryos to the blastocyst stage for experiment 4 (treatment from d 0 to 7.5 ), experiment 5 (treatment from d 0 to 4), and experiment 6 (treatment from d 4 to 7.5 ) are presented in Figure 4. When added throughout culture from d 0 to 7.5 after insemination, concentration of IL-6 affected the percent of presumptive embryos becoming blastocysts. Fewer embryos became blastocysts when embryos were cultured with $5 \mathrm{ng} / \mathrm{mL}$ IL-6 than when cultured with vehicle or other concentrations of IL-6 $(P=0.0271)$. There was no effect of IL-6 on development to the blastocyst stage when added from d 0 to 4 of development or from d 4 to 7.5 of development.
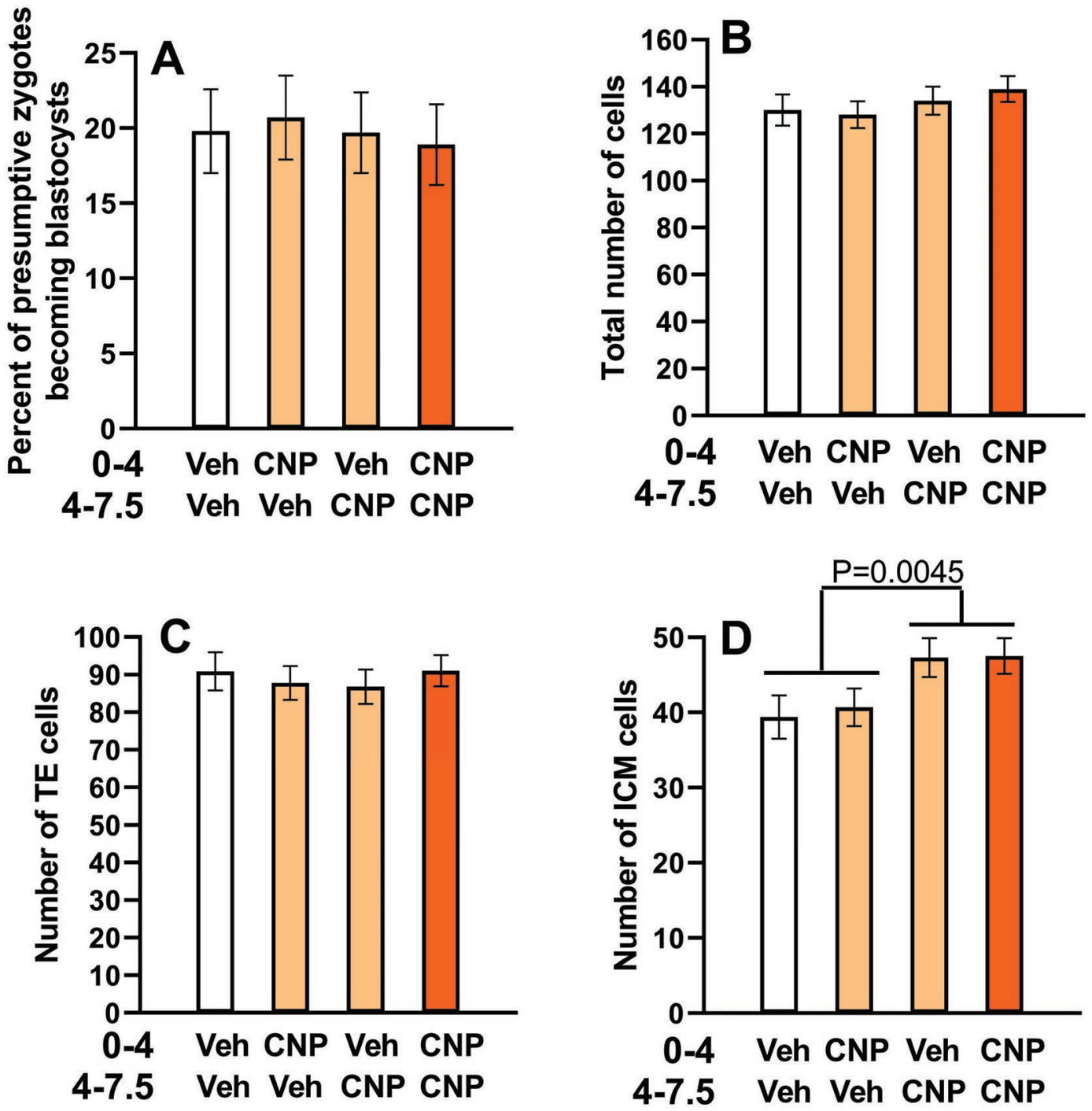

Figure 1. Effects of $200 \mathrm{n} M$ C-natriuretic peptide (CNP) or vehicle (Veh) added from d 0 to 4,4 to 7.5 , or 0 to 7.5 on the percent of presumptive zygotes that became blastocysts (A), the total cell number of cells in the resultant blastocysts (B), number of trophectoderm (TE) cells in blastocysts (C) and number of inner cell mass (ICM) cells in blastocysts (D). Results are LSM \pm SEM. There was an effect of addition of CNP from d 4 to 7.5 on number of ICM cells $(P=0.0045)$. 
Actions of LIF and IL-6 to Activate STAT3 Signaling and Regulate Number of Total and NANOG-Positive Cells in the Blastocyst (Experiment 7)

Experiment 7 had several goals. The first was to evaluate developmental actions of IL- 6 at a higher concentration $(100 \mathrm{ng} / \mathrm{mL})$ than used in experiments 1,2 , and 3 . The effect of LIF, another IL-6-class cytokine whose gene is expressed at $\mathrm{d} 5$ and 7 after ovulation (Oliveira et al., 2013), was also examined. We also verified that both molecules were biologically active by showing that treatment increased labeling for the downstream cellsignaling molecule pSTAT3. Finally, we tested whether either molecule would increase the number of cells in the ICM positive for the pluripotency factor NANOG.

Neither IL-6 nor LIF affected the percent of presumptive zygotes that became blastocysts (Figure 5A) or blastocyst total cell number (Figure 5B). Representative images of labeling of blastocysts for pSTAT3 and NANOG are shown in Figure 6. Cells positive for pSTAT3 were limited to the ICM. Interleukin-6 increased $(P=0.0002)$, and LIF tended $(P=0.0790)$ to increase, the percent of cells that were positive for pSTAT3 (Figure 5C). Treatment with IL-6 also increased $(P<0.0001)$ intensity of pSTAT3 labeling for pSTAT $^{+}$cells (Figure 5D) and there was a tendency
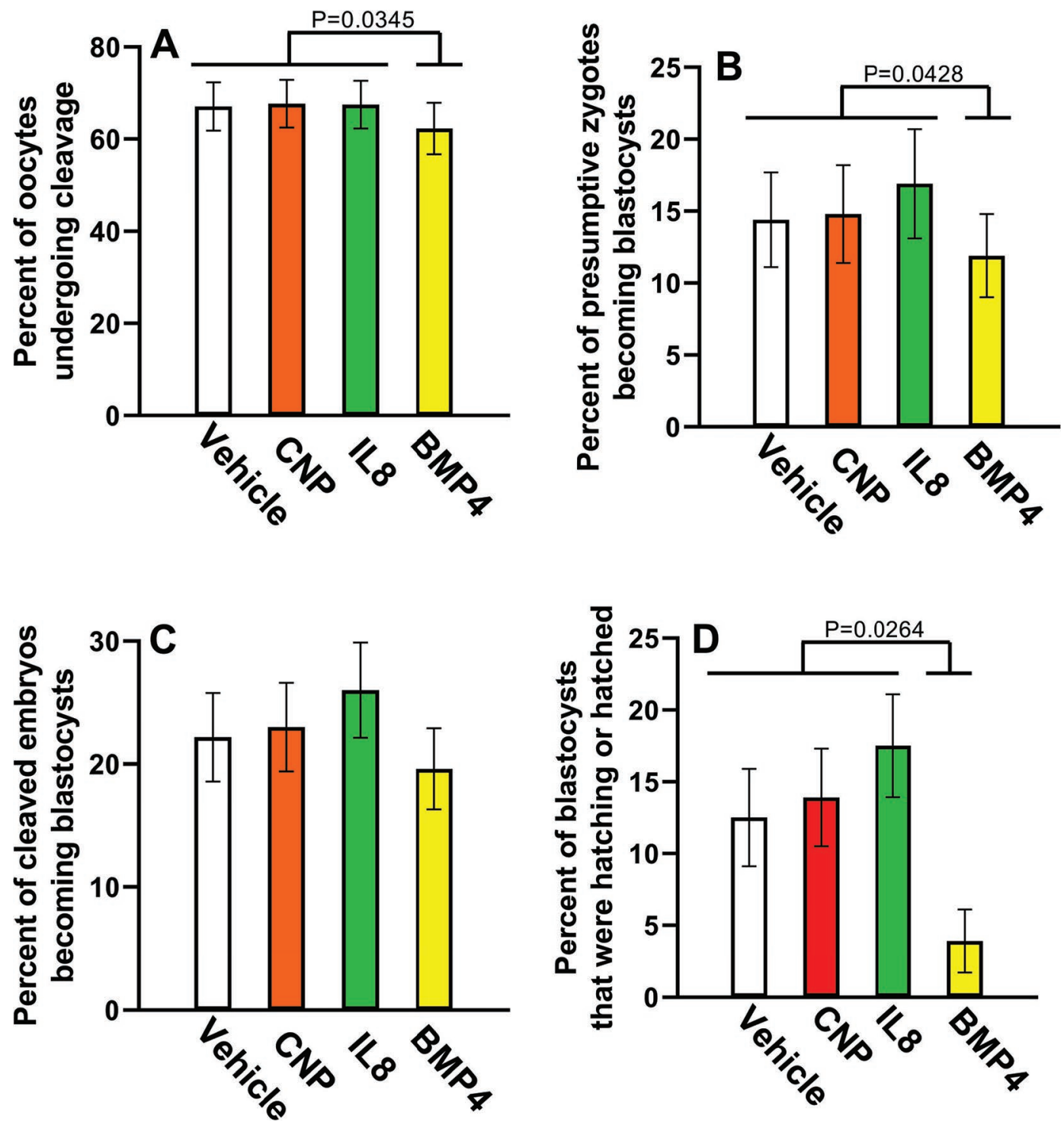

Figure 2. Effects of $200 \mathrm{n} M$ C-natriuretic peptide (CNP), $100 \mathrm{ng} / \mathrm{mL}$ IL-8, and $100 \mathrm{ng} / \mathrm{mL}$ bone morphogenetic protein 4 (BMP-4) on percent of oocytes that cleaved after fertilization with X-sorted semen (A), percent of presumptive zygotes that became blastocysts (B), percent of cleaved embryos that became blastocysts $(\mathrm{C})$, and percent of blastocysts that were hatching or hatched at d 7.5 after insemination. Results are $\mathrm{LSM} \pm$ SEM. Significant effects of BMP-4 compared with other treatments are indicated by the lines above the bars. 

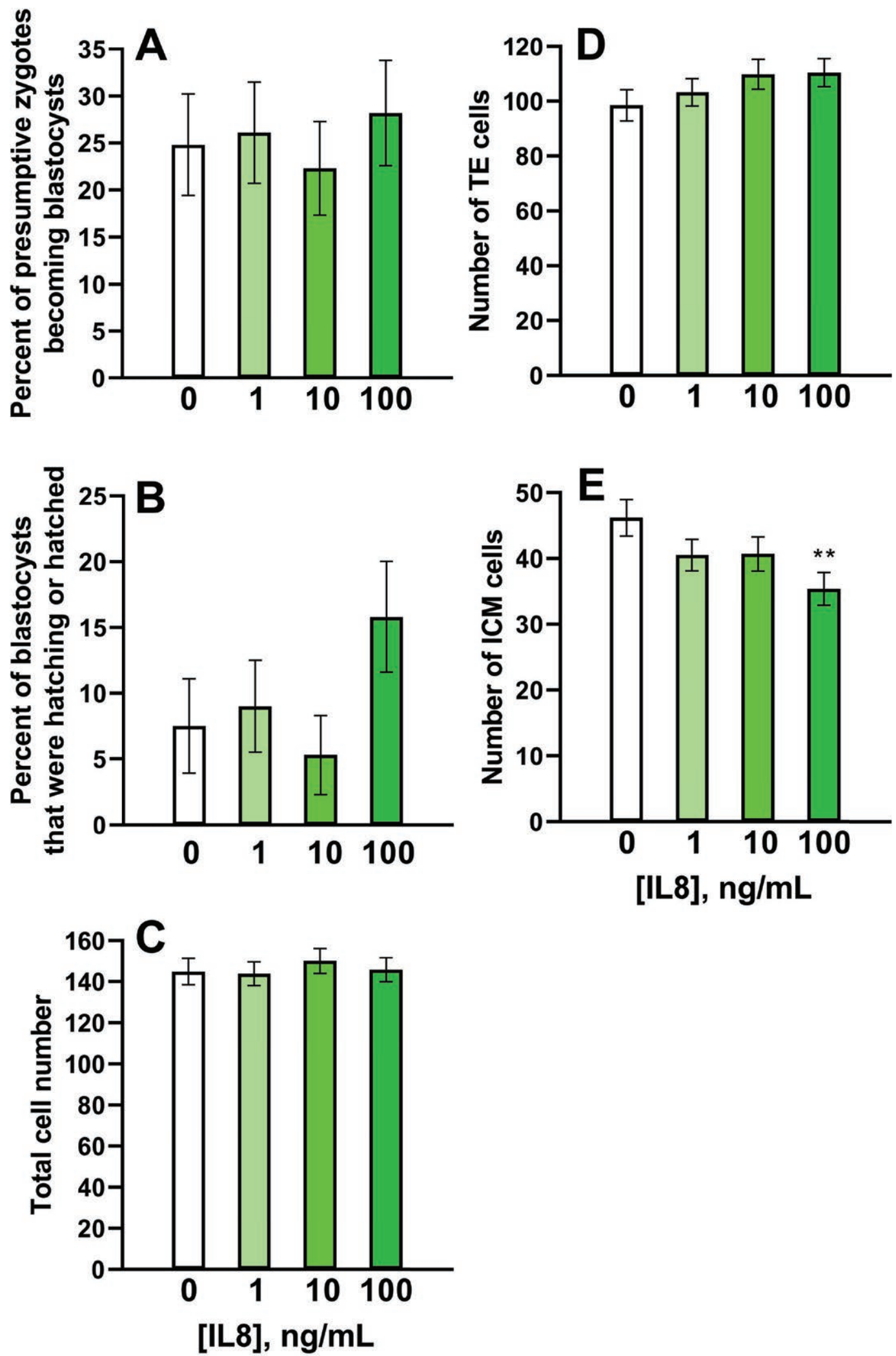

Figure 3. Concentration-dependent effects of IL-8 from d 0 to 7.5 after insemination on percent of presumptive zygotes that became blastocysts (A), percent of blastocysts at d 7.5 that were hatching or hatched (B), total cell number of blastocysts (C), trophectoderm (TE) cell number (D), and inner cell mass (ICM) cell number (E). Results are LSM \pm SEM. Means that differed from 0 are indicated by asterisks $(P=0.0041)$. 


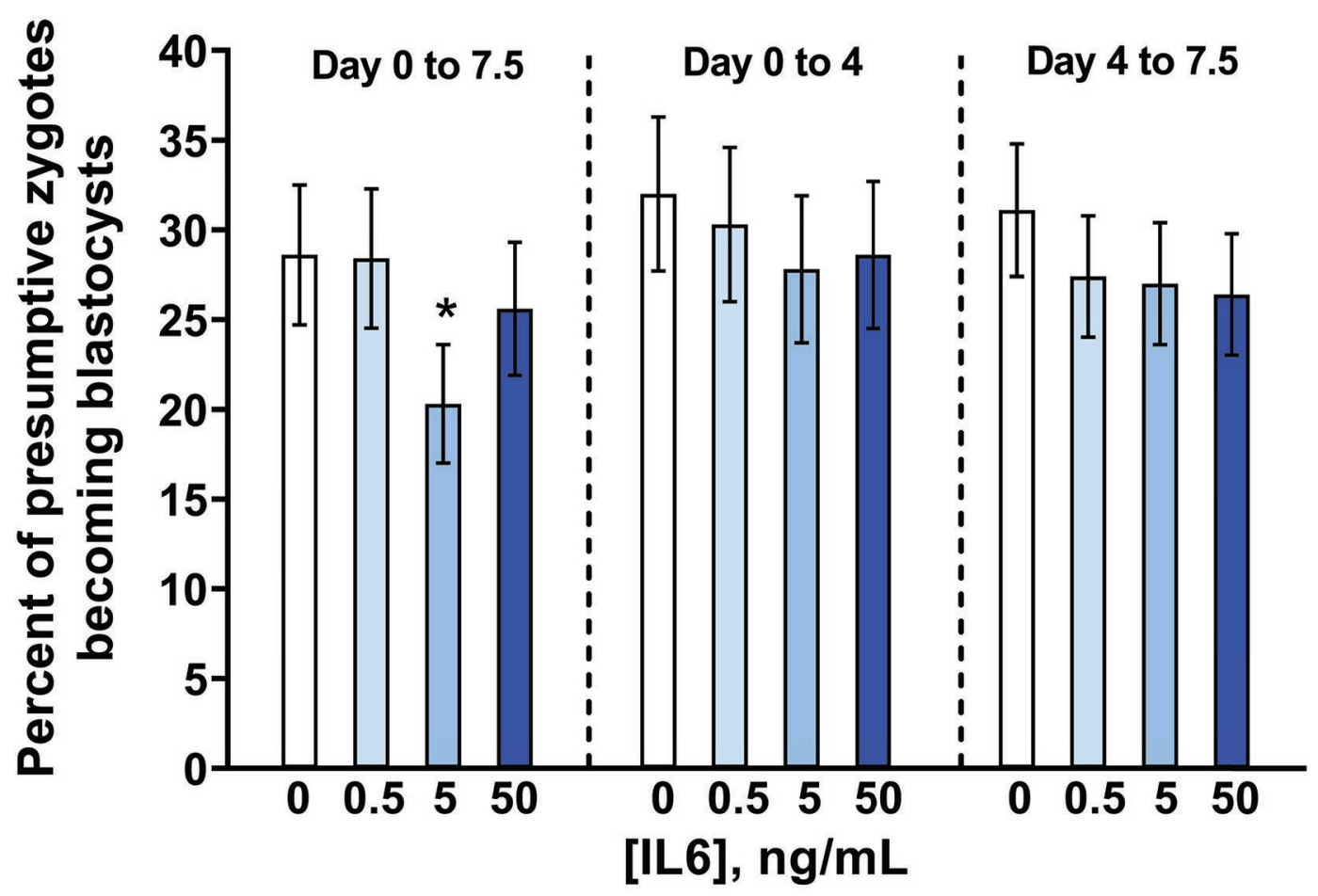

Figure 4. Effects of IL-6 concentration during culture from d 0 to 7.5, 0 to 4, and 4 to 7.5 after insemination on the percent of presumptive zygotes that became blastocysts. Results are LSM \pm SEM. Means that differ from $0 \mathrm{ng} / \mathrm{mL}$ are indicated by an asterisk $(P=0.0271)$.

$(P=0.0804)$ for LIF to cause a much smaller increase in intensity of pSTAT3 labeling (Figure 5D).

Cells positive for NANOG were also limited to the ICM (Figure 6) but there were fewer cells in the ICM positive for NANOG than for pSTAT3 (compare Figure $5 \mathrm{C}$ and $7 \mathrm{~A}$ ). Treatment had no effect on the intensity of labeling for NANOG (Figure 7B). The number of cells that were positive for both NANOG and pSTAT3 was low but LIF increased $(P=0.0394)$ the number of these cells (Figure 7C).

\section{DISCUSSION}

The experiments described here were conducted to evaluate the actions of various cell-signaling molecules expressed in the bovine endometrium on the ability of embryos to develop to the blastocyst stage and on various morphological, developmental, and functional characteristics of the blastocysts themselves. Transcripts for the genes encoding all of the molecules examinedCNP, IL-8, BMP-4, IL-6, and LIF-are expressed in the endometrium at d 5 to 7 after estrus (Forde et al., 2011; Oliveira et al., 2013; Moran et al., 2017; Sá Filho et al., 2017; Tríbulo et al., 2018b). This is the period following entry of the embryo into the uterus at $\mathrm{d} 4$ to 5 (Hackett et al., 1993) when the embryo undergoes processes that culminate in formation of the blastocyst.
At this point, the embryo has completed the first differentiation event in development leading to formation of the ICM and TE (Hansen and Tríbulo, 2019). The results reported here indicate that none of the cellsignaling molecules tested improved the competence of the embryo to become a blastocyst - indeed, BMP-4 decreased development in female embryos - but several molecules modified the nature of the blastocyst that was formed in culture. In particular, CNP increased the number of cells in the ICM; IL-8 decreased ICM cell numbers and tended to increase the proportion of blastocysts that were undergoing hatching; BMP-4 decreased the proportion of female blastocysts that were hatching; IL-6 and, to a lesser extent, LIF, activated the JAK/STAT3 signaling pathway in the ICM; and LIF increased the percent of cells in the blastocyst that were positive for both NANOG and pSTAT3.

The finding that competence of embryos to become blastocysts in vitro was largely unaffected by cellsignaling molecules is consistent with other findings in the literature. Most important are the observations of Rizos et al. (2002), who found that conditions of oocyte maturation and fertilization were a more important determinant of embryo competence to develop to the blastocyst stage than conditions after the embryo was formed. When oocytes were matured and fertilized in vivo and cultured in vitro, up to $74 \%$ became 
blastocysts compared with $39 \%$ when maturation, fertilization, and embryo culture were performed in vitro. Furthermore, Rizos et al. (2002) observed that placing in vitro-produced embryos in the sheep oviduct did not increase the percent that became blastocysts. Other experiments also indicated little effect of CNP (Costa et al., 2020) or IL-6 (Wooldridge and Ealy, 2019) on the competence of embryos to become blastocysts. Reports are variable regarding actions of LIF on development, with some reports indicating increased development to the blastocyst stage (Neira et al., 2010) and others reporting an inhibition in development (Sirisathien et al., 2003; Rodríguez et al., 2007).

The conclusion that the largest determinant of whether an oocyte becomes a blastocyst are the conditions during oocyte maturation and fertilization rather than after the embryo has formed does not mean that the environment of the embryo is not important. Regu-
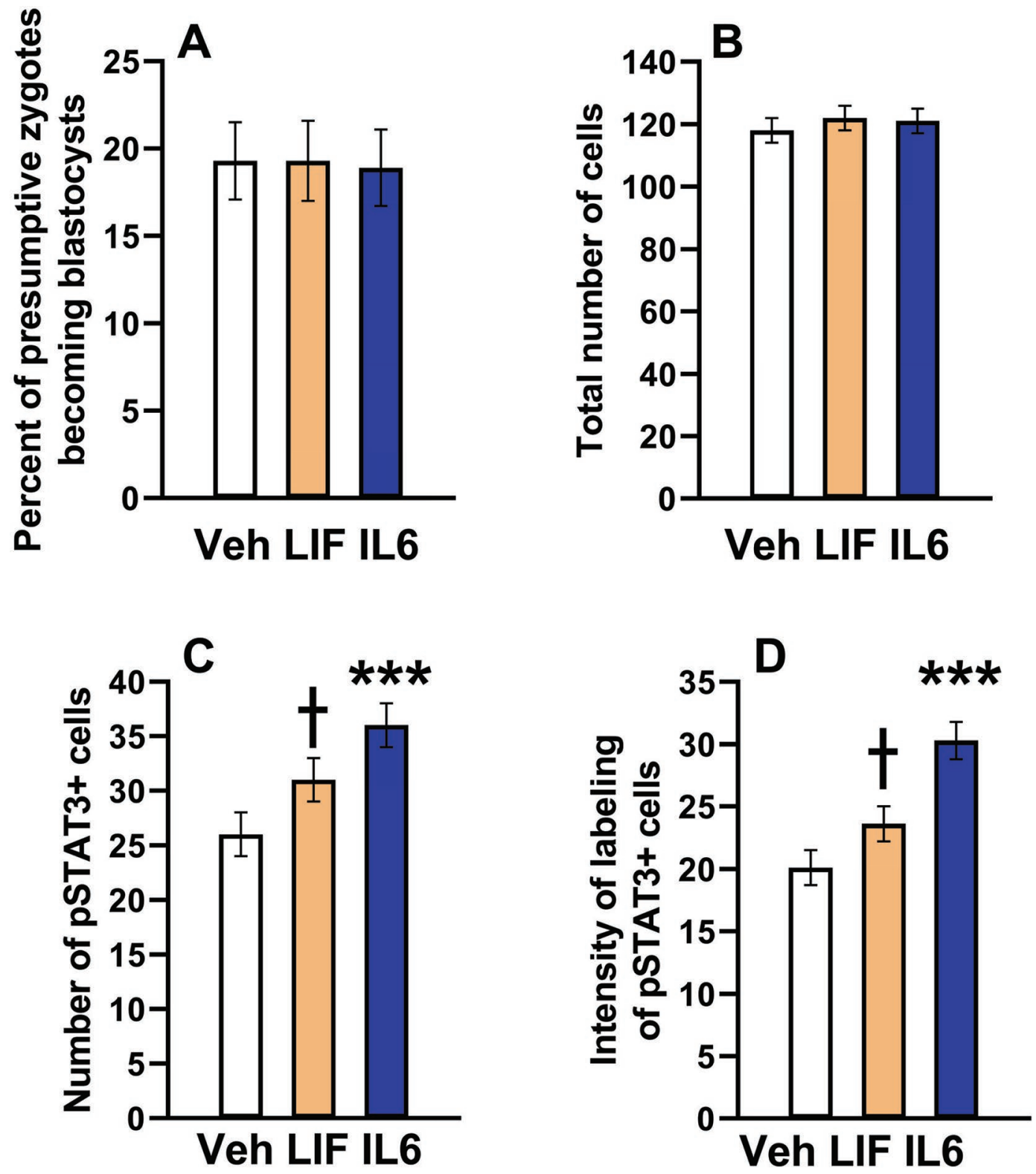

Figure 5. Effects of $100 \mathrm{ng} / \mathrm{mL}$ leukemia inhibitory factor (LIF) and $100 \mathrm{ng} / \mathrm{mL}$ IL-6 or vehicle (Veh) from d 4 to 7.5 after insemination on the percent of presumptive zygotes that became blastocysts (A), total cell number of blastocysts (B), number of phosphorylated STAT3-positive (pSTAT3+) cells $(\mathrm{C})$, and intensity of labeling of pSTAT3+ cells (D). Results are LSM \pm SEM. The number of pSTAT3+ cells was increased $(P=0.0002)$ by IL-6 $(* * *)$ and tended $(P=0.0790)$ to be increased by LIF $(\dagger)$. Intensity of pSTAT3 labeling for pSTAT3+ cells was increased by IL-6 $(P<0.0001)$ and tended $(P=0.0804)$ to be increased by LIF. 


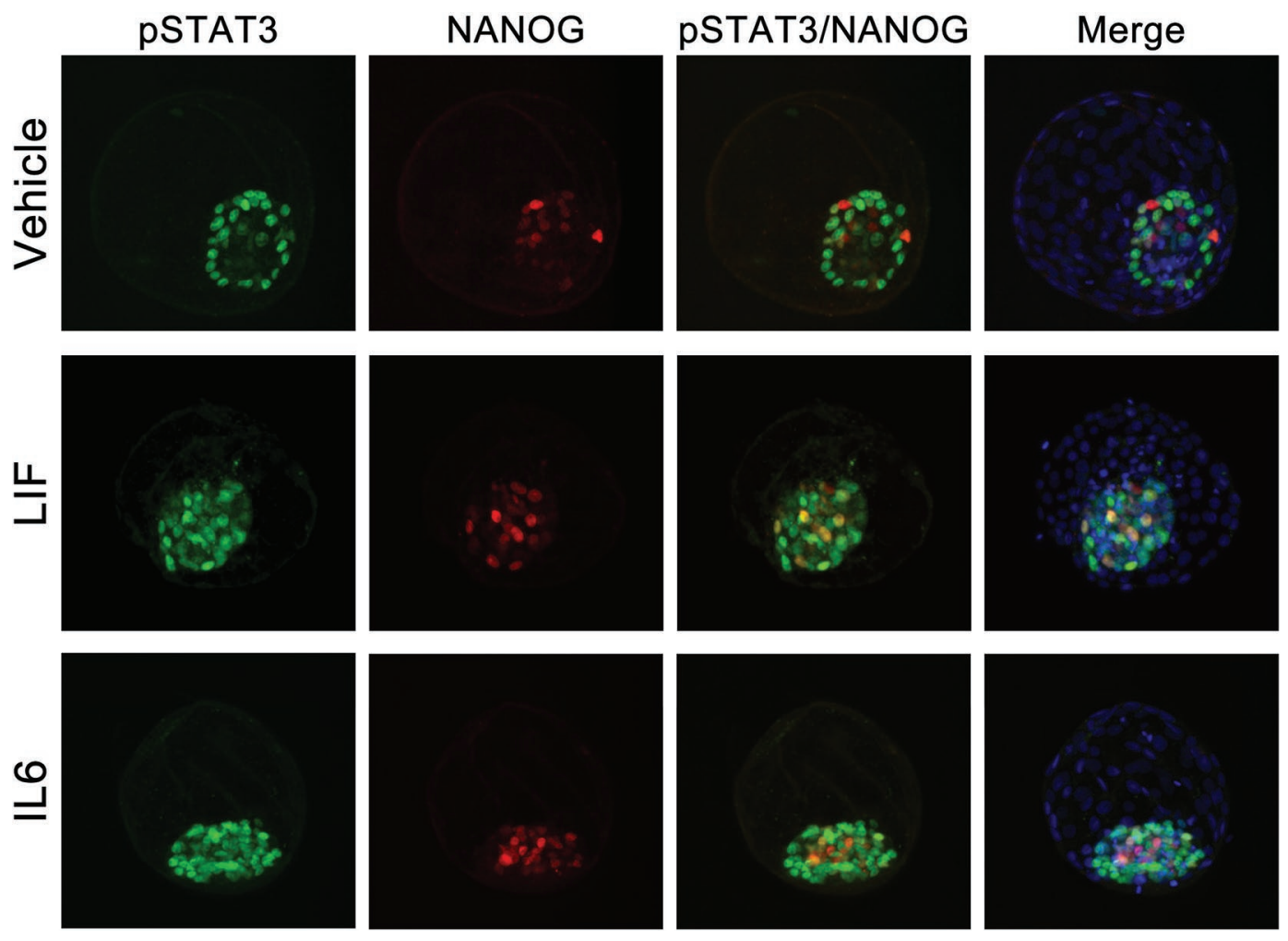

Figure 6. Representative images of blastocysts labeled for phosphorylated (p)STAT3 (green), NANOG (red), and Hoechst 33342 (blue). Images represent maximum projections of z-stack images obtained by confocal microscopy of d 7.5 blastocysts treated with vehicle (Veh), IL-6, or leukemia inhibitory factor (LIF). Magnification $=20 \times$. Pseudo-green was used for visualization of pSTAT3.

latory signals are more likely to affect the nature of the blastocyst that is formed rather than whether the embryo becomes a blastocyst. Consistent with this idea are the current findings that CNP increased number of ICM cells, IL-8 decreased ICM cell number, and BMP4 reduced the proportion of female blastocysts that were undergoing hatching. Several other cell-signaling molecules have been identified that changed numbers of ICM or TE cells without affecting the percent of embryos becoming blastocysts. These include CTGF and teratoma-derived growth factor 1 (KannampuzhaFrancis et al., 2017). Also, IL-6 has been shown earlier to increase number of ICM cells (Wooldridge and Ealy, 2019). When embryokines affecting percent blastocyst have been identified, the magnitude of the increase was small. Examples are activin A (Kannampuzha-Francis et al., 2017; Tríbulo et al., 2018a), WNT7A (Tríbulo et al., 2017, 2018a), CSF2 (Loureiro et al., 2009), and FGF2 (Fields et al., 2011). It is likely that only a fraction of the embryos placed in culture are able to have developmental competence modified by specific embryokines after fertilization. A larger fraction are likely to be derived from oocytes that are not capable of becoming blastocysts, regardless of the embryokine milieu.
In the current experiments, CNP increased the number of ICM cells in the blastocyst and IL-8 decreased ICM cell numbers. It is not known what the consequences of changes in ICM cell numbers are for the blastocyst. At least for in vitro-produced embryos, about $25 \%$ of embryos that survive to d 14 to 15 have lost the embryonic disk (Fischer-Brown et al., 2004; Block et al., 2007; Loureiro et al., 2011), suggesting that ICM cell numbers might be important for survival of the embryo later in development. Morphological characteristics of the ICM have also been related to pregnancy outcomes after transfer in the human in some (Nazem et al., 2019; Boynukalin et al., 2020) but not all (Bakkensen et al., 2019) studies.

Further work is needed to understand the mechanism by which a molecule such as CNP can affect formation of the ICM. Because treatment of embryos with CNP at d 4 caused an increase in ICM cell numbers equivalent to that of treatment after fertilization, we can conclude that CNP is acting on the embryo at d 4 or later in development. Once the tight junctions between outer cells of the morula form (at about the 32- to 64-cell stage; Hansen and Tríbulo, 2019), CNP would not be able to directly regulate inner cells of the embryo. It is likely, therefore, that CNP either affects the differentiation of 
precursors of ICM before tight junction formation or acts on TE cells to indirectly affect ICM function.

Three of the molecules tested in the current study may participate in modification of embryonic development caused by specific inflammatory events in the endometrium. Both IL 6 and IL 8 are among the genes whose expression is increased in bovine endometrium associated with subclinical endometritis (Fagundes et al., 2019) and CNP is a constituent of bull seminal plasma (Chrisman et al., 1993). More research is required but evidence from this and other experiments would indicate that CNP and IL-6 would be facilitatory to embryo survival given the effects of CNP (this study) and IL-6 (Wooldridge et al., 2019; Wooldridge and Ealy, 2019) to increase ICM cell number and of IL-6 to activate JAK/STAT signaling in ICM (Wooldridge and Ealy, 2019; this study). Implications of IL-8 exposure for embryonic development are less clear. Only the highest concentration tested $(100 \mathrm{ng} / \mathrm{mL})$ affected characteristics of the blastocyst. The decrease in numbers of ICM cells might reflect reduced survival of the embryonic disk later in gestation. Although not significant, IL-8 also tended to increase the percent of blastocysts that were undergoing hatching in both experiments in which it was evaluated. Such a result reflects alterations in blastocyst function caused by IL-8.

The one molecule that was clearly inhibitory to embryonic development was BMP-4. Treatment of embryos produced using X-sorted semen with BMP-4 decreased the percent of embryos that became blastocysts as well as the percent of blastocysts that were undergoing hatching. This inhibitory effect of BMP-4, a member of the transforming growth factor- $\beta$ family, is consistent with earlier experiments that BMP-4 can inhibit the ability of embryos from the cow (La Rosa et al., 2011), mouse (Home et al., 2012), and human (De Paepe et al., 2019) to develop to the blastocyst stage. In addition, BMP-4 can induce apoptosis in the human blastocyst (De Paepe et al., 2019). The BMP4 gene is expressed in the oviduct and endometrium throughout the first $7 \mathrm{~d}$ after ovulation in cattle (Tríbulo et al., $2018 \mathrm{~b}$ ) and it is not clear whether it exerts an inhibitory action on embryonic development in vivo. However, BMP-4 can affect cellular function by activating a variety of different signaling pathways (Shen et al., 2020) and it is possible that the particular action of BMP-4 depends on cellular context. Specific microRNAs can block the antiapoptotic actions of BMP-4 (Musto et al., 2015), and perhaps other cell-signaling molecules mitigate against the antidevelopmental actions of BMP-4 in vivo.

Embryos with a knockout genotype for the $\beta$ subunit of the LIF receptor can develop until close to term (Ware et al., 1995). Mouse embryonic stem cells can also be maintained in a pluripotent state with LIF treatment (Williams et al., 1988), although this role is not conserved in humans (Reubinoff et al., 2000). Leukemia inhibitory factor is a member of the IL-6 family and, like IL-6, utilizes the gp130 receptor unit as part of its receptor and can activate JAK/STAT3 signaling (RoseJohn, 2018). However, the LIF receptor complex differs from that of IL- 6 and, although the 2 cytokines can activate several cell-signaling pathways including JAK/ STAT3, IL-6 has a greater capacity for transactivation of receptors for other members of the IL-6 family than does LIF (Nicola and Babon, 2015; Rose-John, 2018). Here, we demonstrated that IL-6 increased the number of $\mathrm{pSTAT}^{+}$cells in the ICM as well as intensity of
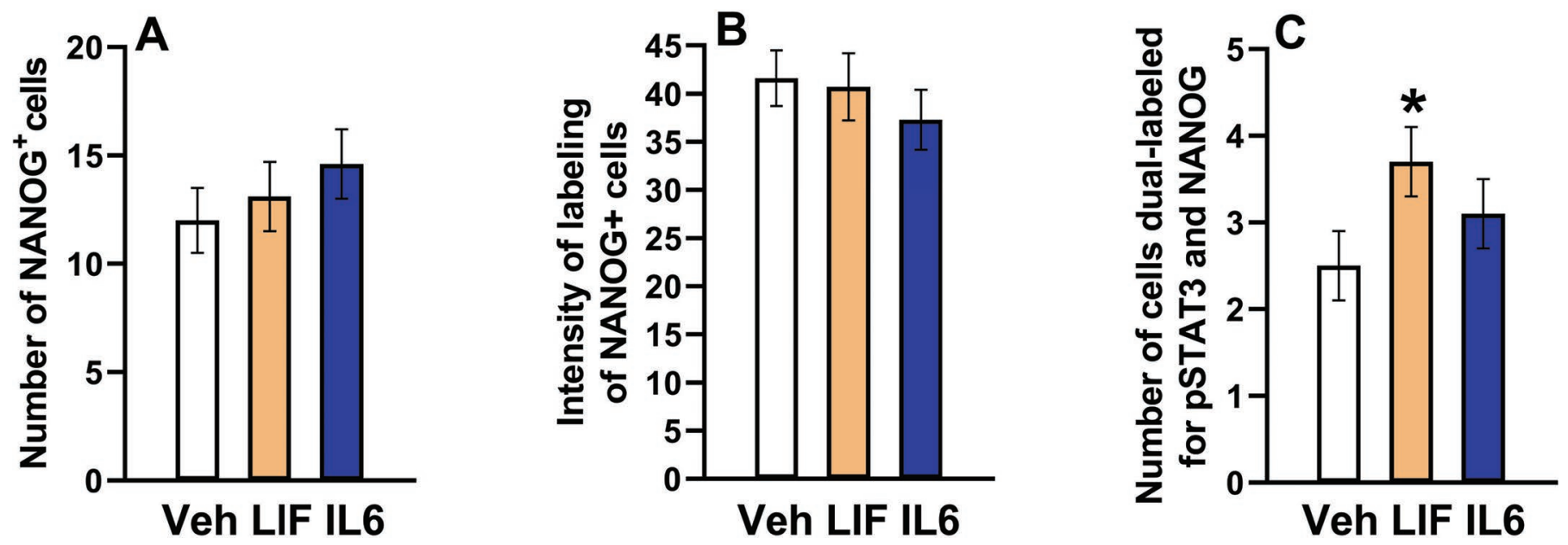

Figure 7. Effects of $100 \mathrm{ng} / \mathrm{mL}$ leukemia inhibitory factor (LIF) and $100 \mathrm{ng} / \mathrm{mL}$ IL-6 from d 4 to 7.5 after insemination on the number of $\mathrm{NANOG}^{+}$cells (A), intensity of labeling of $\mathrm{NANOG}^{+}$cells (B), and the number of cells positive for both NANOG and phosphorylated (p)STAT3 (C). Results are LSM \pm SEM. The number of dual-labeled cells was increased $(P=0.0394)$ by LIF $\left(^{*}\right)$. 
labeling for pSTAT3. There was also a tendency for LIF to increase the number of positive cells for pSTAT3, but the extent of activation was much less than that for IL-6. There was no evidence to support earlier observations that LIF can either increase (Neira et al., 2010) or decrease the percent of embryos becoming blastocysts (Sirisathien et al., 2003; Rodríguez et al., 2007).

One action of LIF that was not shared by IL-6 was increasing the number of cells in the blastocyst that were dual-labeled for NANOG and pSTAT3. Such a result is further confirmation that the 2 related cytokines have differential actions on the bovine embryo. One possibility is that IL-6 is acting primarily on cells in the ICM that differentiate into hypoblast (precursor of the yolk sac) whereas LIF is acting on cells that will become epiblast. This speculation is based on observations that treatment of bovine embryos with IL-6 increased blastocyst expression of genes characteristic of hypoblast but not genes characteristic of ICM (Wooldridge et al., 2019). The idea that LIF is acting on cells destined to be epiblast is based on the importance of LIF for maintenance of pluripotency in mice (Williams et al., 1988).

It is important to recognize the limitations of the experimental system to evaluate potential embryokines. Some cell-signaling molecules, such as HDGF, can either inhibit or promote development to the blastocyst stage, depending on the day of development that treatment is initiated (Gómez et al., 2014). Lack of effect of a cell-signaling molecule could be because the embryo itself can produce the embryokine. The BSA often used in embryo culture has been shown to contain HDGF (Gómez et al., 2017) and could contain other bioactive molecules. It is also likely that specific embryokines interact with each other, as has been shown for a cocktail of cell-signaling molecules tested by Neira et al. (2010).

In conclusion, the results reported here indicate that CNP, IL-8, IL-6, LIF, and BMP-4 can modify embryonic development of the cow in a manner that affects characteristics of the resultant blastocyst. Bone morphogenetic protein- 4 was the one cell-signaling molecule that was inhibitory to development of the embryo to the blastocyst stage. Further research is required to understand how changes in characteristics of the blastocyst described here would affect competence of the embryo to establish and maintain pregnancy. It is possible that actions of CNP would promote survival of the embryo by increasing the number of cells in the ICM, whereas the negative effect of IL-8 on ICM number might reduce competence of the blastocyst for survival.

\section{ACKNOWLEDGMENTS}

Research was supported by the National Institutes of Health (Bethesda, MD) grant R01 HD088352 and the
L. E. "Red" Larson Endowment. The authors acknowledge Eddie Cummings for ovary collection and owners of Florida Beef Inc. (Zolfo Springs, FL) for providing ovaries. The authors extend their thanks to the students in the laboratory for technical assistance. The authors state no conflicts of interest.

\section{REFERENCES}

Akthar, I., S. Suarez, V. A. Morillo, M. Sasaki, M. A. Ezz, K. I. Takahashi, M. Shimada, M. A. Marey, and M. Miyamoto. 2020. Sperm enter glands of preovulatory bovine endometrial explants and initiate inflammation. Reproduction 159:181-192. https://doi .org/10.1530/REP-19-0414.

Bakkensen, J. B., P. Brady, D. Carusi, P. Romanski, A. M. Thomas, and C. Racowsky. 2019. Association between blastocyst morphology and pregnancy and perinatal outcomes following fresh and cryopreserved embryo transfer. J. Assist. Reprod. Genet. 36:23152324. https://doi.org/10.1007/s10815-019-01580-0.

Block, J., A. E. Fischer-Brown, T. M. Rodina, A. D. Ealy, and P. J. Hansen. 2007. The effect of in vitro treatment of bovine embryos with IGF-1 on subsequent development in utero to Day 14 of gestation. Theriogenology 68:153-161. https://doi.org/10.1016/ j.theriogenology.2007.04.045.

Block, J., and P. J. Hansen. 2007. Interaction between season and culture with insulin-like growth factor-1 on survival of in vitro produced embryos following transfer to lactating dairy cows. Theriogenology 67:1518-1529. https://doi.org/10.1016/j.theriogenology .2007.03.012.

Boynukalin, F. K., M. Gultomruk, S. Cavkaytar, E. Turgut, N. Findikli, M. Serdarogullari, O. Coban, Z. Yarkiner, C. Rubio, and M. Bahceci. 2020. Parameters impacting the live birth rate per transfer after frozen single euploid blastocyst transfer. PLoS One 15:e227619. https://doi.org/10.1371/journal.pone.0227619.

Bromfield, J. J. 2018. Review: The potential of seminal fluid mediated paternal-maternal communication to optimise pregnancy success. Animal 12(s1):s104-s109. https://doi.org/10.1017/ S1751731118000083.

Chrisman, T. D., S. Schulz, L. R. Potter, and D. L. Garbers. 1993. Seminal plasma factors that cause large elevations in cellular cyclic GMP are C-type natriuretic peptides. J. Biol. Chem. 268:36983703.

Costa, C. B., P. A. Lunardelli, P. K. Fontes, M. J. Sudano, M. F. Gouveia Nogueira, A. A. Alfieri, C. R. Ferreira, C. B. de Lima, L. S. R. Marinho, and M. M. Seneda. 2020. Influence of cAMP modulator supplementation of in vitro culture medium on Bos taurus indicus embryos. Theriogenology 141:134-141. https://doi.org/10.1016/j theriogenology.2019.09.007.

Denicol, A. C., J. Block, D. E. Kelley, K. G. Pohler, K. B. Dobbs, C. J. Mortensen, M. S. Ortega, and P. J. Hansen. 2014. The WNT signaling antagonist Dickkopf-1 directs lineage commitment and promotes survival of the preimplantation embryo. FASEB J. 28:3975-3986. https://doi.org/10.1096/fj.14-253112.

De Paepe, C., A. Aberkane, D. Dewandre, W. Essahib, K. Sermon, M. Geens, G. Verheyen, H. Tournaye, and H. Van de Velde. 2019. BMP4 plays a role in apoptosis during human preimplantation development. Mol. Reprod. Dev. 86:53-62. https://doi.org/10.1002/ mrd.23081.

Dobbs, K. B., D. Gagné, E. Fournier, I. Dufort, C. Robert, J. Block, M. A. Sirard, L. Bonilla, A. D. Ealy, B. Loureiro, and P. J. Hansen. 2014. Sexual dimorphism in developmental programming of the bovine preimplantation embryo caused by colony-stimulating factor 2. Biol. Reprod. 91:80. https://doi.org/10.1095/biolreprod .114 .121087 .

Ealy, A. D., L. K. Wooldridge, and S. R. McCoski. 2019. Board Invited Review: Post-transfer consequences of in vitro-produced embryos in cattle. J. Anim. Sci. 97:2555-2568. https://doi.org/10.1093/jas/ skz116. 
Fagundes, N. S., A. L. Rezende, P. B. Alvarenga, L. Q. Magalhães, R. M. Santos, S. A. Headley, M. J. B. Silva, M. E. Beletti, and J. P. E. Saut. 2019. Short communication: Proinflammatory gene expression relative to the collection technique of endometrial samples from cows with and without subclinical endometritis. J. Dairy Sci. 102:5511-5517. https://doi.org/10.3168/jds.2018-15212.

Fields, S. D., P. J. Hansen, and A. D. Ealy. 2011. Fibroblast growth factor requirements for in vitro development of bovine embryos. Theriogenology 75:1466-1475. https://doi.org/10.1016/j .theriogenology.2010.12.007.

Fischer-Brown, A. E., B. R. Lindsey, F. A. Ireland, D. L. Northey, R. L. Monson, S. G. Clark, M. B. Wheeler, D. J. Kesler, S. J. Lane, K. A. Weigel, and J. J. Rutledge. 2004. Embryonic disc development and subsequent viability of cattle embryos following culture in two media under two oxygen concentrations. Reprod. Fertil. Dev. 16:787-793. https://doi.org/10.1071/rd04026.

Forde, N., M. E. Beltman, G. B. Duffy, P. Duffy, J. P. Mehta, P. O'Gaora, J. F. Roche, P. Lonergan, and M. A. Crowe. 2011. Changes in the endometrial transcriptome during the bovine estrous cycle: effect of low circulating progesterone and consequences for conceptus elongation. Biol. Reprod. 84:266-278. https://doi .org/10.1095/biolreprod.110.085910.

Gómez, E., S. Carrocera, D. Martin, M. J. Sánchez-Calabuig, A. Gutiérrez-Adán, A. Murillo, and M. Muñoz. 2017. Hepatoma-derived growth factor: Protein quantification in uterine fluid, gene expression in endometrial-cell culture and effects on in vitro embryo development, pregnancy and birth. Theriogenology 96:118125. https://doi.org/10.1016/j.theriogenology.2017.04.008.

Gómez, E., E. Correia-Alvarez, J. N. Caamaño, C. Díez, S. Carrocera, N. Peynot, D. Martín, C. Giraud-Delville, V. Duranthon, O. Sandra, and M. Muñoz. 2014. Hepatoma-derived growth factor: From the bovine uterus to the in vitro embryo culture. Reproduction 148:353-365. https://doi.org/10.1530/REP-14-0304.

Hackett, A. J., R. Durnford, R. Mapletoft, and G. Marcus. 1993. Location and status of embryos in the genital tract of superovulated cows 4 to 6 days after insemination. Theriogenology 40:1147-1153. https://doi.org/10.1016/0093-691X(93)90285-D.

Hansen, P. J. 2020. Implications of assisted reproductive technologies for pregnancy outcomes in mammals. Annu. Rev. Anim. Biosci. 8:395-413. https://doi.org/10.1146/annurev-animal-021419 -084010 .

Hansen, P. J., and P. Tríbulo. 2019. Regulation of present and future development by maternal regulatory signals acting on the embryo during the morula to blastocyst transition-Insights from the cow. Biol. Reprod. 101:526-537. https://doi.org/10.1093/biolre/ioz030.

Helfrich, A. L., H. D. Reichenbach, M. M. Meyerholz, H. A. Schoon, G. J. Arnold, T. Fröhlich, F. Weber, and H. Zerbe. 2020. Novel sampling procedure to characterize bovine subclinical endometritis by uterine secretions and tissue. Theriogenology 141:186-196. https:/ /doi.org/10.1016/j.theriogenology.2019.09.016.

Home, P., B. Saha, S. Ray, D. Dutta, S. Gunewardena, B. Yoo, A. Pal, J. L. Vivian, M. Larson, M. Petroff, P. G. Gallagher, V. P. Schulz, K. L. White, T. G. Golos, B. Behr, and S. Paul. 2012. Altered subcellular localization of transcription factor TEAD4 regulates first mammalian cell lineage commitment. Proc. Natl. Acad. Sci. USA 109:7362-7367. https://doi.org/10.1073/pnas.1201595109.

Jannaman, E. A., Y. Xiao, and P. J. Hansen. 2020. Actions of colony stimulating factor 3 on the maturing oocyte and developing embryo in cattle. J. Anim. Sci. 98:skaa115. https://doi.org/10.1093/ jas/skaa115.

Kannampuzha-Francis, J., P. Tribulo, and P. J. Hansen. 2017. Actions of activin A, connective tissue growth factor, hepatocyte growth factor and teratocarcinoma-derived growth factor 1 on the development of the bovine preimplantation embryo. Reprod. Fertil. Dev. 29:1329-1339. https://doi.org/10.1071/RD16033.

Kimura, T., H. Kohno, Y. Matsuoka, M. Murakami, R. Nakatsuka, M. Hase, K. Yasuda, Y. Uemura, Y. Sasaki, S. Fukuhara, and Y. Sonoda. 2011. CXCL8 enhances the angiogenic activity of umbilical cord blood-derived outgrowth endothelial cells in vitro. Cell Biol. Int. 35:201-208. https://doi.org/10.1042/CBI20090225.
La Rosa, I., L. Camargo, M. M. Pereira, R. Fernandez-Martin, D. A. Paz, and D. F. Salamone. 2011. Effects of bone morphogenic protein 4 (BMP4) and its inhibitor, Noggin, on in vitro maturation and culture of bovine preimplantation embryos. Reprod. Biol. Endocrinol. 9:18. https://doi.org/10.1186/1477-7827-9-18.

Loureiro, B., J. Block, M. G. Favoreto, S. Carambula, K. A. Pennington, A. D. Ealy, and P. J. Hansen. 2011. Consequences of conceptus exposure to colony-stimulating factor 2 on survival, elongation, interferon- $\tau$ secretion, and gene expression. Reproduction 141:617-624. https://doi.org/10.1530/REP-10-0511.

Loureiro, B., L. Bonilla, J. Block, J. M. Fear, A. Q. Bonilla, and P. J. Hansen. 2009. Colony-stimulating factor 2 (CSF-2) improves development and posttransfer survival of bovine embryos produced in vitro. Endocrinology 150:5046-5054. https://doi.org/10.1210/ en.2009-0481.

Mesquita, F. S., R. S. Ramos, G. Pugliesi, S. C. Andrade, V. Van Hoeck, A. Langbeen, M. L. Oliveira, A. M. Gonella-Diaza, G. Gasparin, H. Fukumasu, L. H. Pulz, C. M. Membrive, L. L. Coutinho, and M. Binelli. 2015. The receptive endometrial transcriptomic signature indicates an earlier shift from proliferation to metabolism at early diestrus in the cow. Biol. Reprod. 93:52. https://doi .org/10.1095/biolreprod.115.129031.

Moran, B., S. T. Butler, S. G. Moore, D. E. MacHugh, and C. J. Creevey. 2017. Differential gene expression in the endometrium reveals cytoskeletal and immunological genes in lactating dairy cows genetically divergent for fertility traits. Reprod. Fertil. Dev. 29:274-282. https://doi.org/10.1071/RD15128.

Musto, A., A. Navarra, A. Vocca, A. Gargiulo, G. Minopoli, S. Romano, M. F. Romano, T. Russo, and S. Parisi. 2015. miR-23a, miR-24 and miR-27a protect differentiating ESCs from BMP4induced apoptosis. Cell Death Differ. 22:1047-1057. https://doi .org/10.1038/cdd.2014.198.

Nazem, T. G., L. Sekhon, J. A. Lee, J. Overbey, S. Pan, M. Duke, C. Briton-Jones, M. Whitehouse, A. B. Copperman, and D. E. Stein. 2019. The correlation between morphology and implantation of euploid human blastocysts. Reprod. Biomed. Online 38:169-176. https://doi.org/10.1016/j.rbmo.2018.10.007.

Neira, J. A., D. Tainturier, M. A. Peña, and J. Martal. 2010. Effect of the association of IGF-I, IGF-II, bFGF, TGF- $\beta 1$, GM-CSF, and LIF on the development of bovine embryos produced in vitro. Theriogenology 73:595-604. https://doi.org/10.1016/j.theriogenology .2009.10.015.

Nicola, N. A., and J. J. Babon. 2015. Leukemia inhibitory factor (LIF). Cytokine Growth Factor Rev. 26:533-544. https://doi.org/ 10.1016/j.cytogfr.2015.07.001

Oliveira, L. J., N. Mansourri-Attia, A. G. Fahey, J. Browne, N. Forde, J. F. Roche, P. Lonergan, and T. Fair. 2013. Characterization of the Th profile of the bovine endometrium during the oestrous cycle and early pregnancy. PLoS One 8:e75571. https://doi.org/10 .1371/journal.pone.0075571.

Qin, Y. H., F. S. Fan, Y. Zhao, Y. Cui, X. Q. Wei, K. Kohama, J. R. Gordon, F. Li, and Y. Gao. 2013. Recombinant human CXCL8(372)K11R/G31P regulates smooth muscle cell proliferation and migration through blockage of interleukin-8 receptor. IUBMB Life 65:67-75. https://doi.org/10.1002/iub.1107.

Reubinoff, B. E., M. F. Pera, C. Y. Fong, A. Trounson, and A. Bongso. 2000. Embryonic stem cell lines from human blastocysts: Somatic differentiation in vitro. Nat. Biotechnol. 18:399-404. https:/ /doi.org/10.1038/74447.

Rizos, D., F. Ward, P. Duffy, M. P. Boland, and P. Lonergan. 2002 Consequences of bovine oocyte maturation, fertilization or early embryo development in vitro versus in vivo: Implications for blastocyst yield and blastocyst quality. Mol. Reprod. Dev. 61:234-248. https://doi.org/10.1002/mrd.1153.

Rodríguez, A., C. De Frutos, C. Díez, J. N. Caamaño, N. Facal, P. Duque, C. García-Ochoa, and E. Gómez. 2007. Effects of human versus mouse leukemia inhibitory factor on the in vitro development of bovine embryos. Theriogenology 67:1092-1095. https:// doi.org/10.1016/j.theriogenology.2006.11.015. 
Rose-John, S. 2018. Interleukin-6 family cytokines. Cold Spring Harb. Perspect. Biol. 10:a028415. https://doi.org/10.1101/cshperspect .a028415.

Sá Filho, M. F., A. M. Gonella-Diaza, M. Sponchiado, M. F. Mendanha, G. Pugliesi, R. D. S. Ramos, S. C. D. S. Andrade, G. Gasparin, L. L. Coutinho, M. D. Goissis, F. S. Mesquita, P. S. Baruselli, and M. Binelli. 2017. Impact of hormonal modulation at proestrus on ovarian responses and uterine gene expression of suckled anestrous beef cows. J. Anim. Sci. Biotechnol. 8:79. https: //doi.org/10.1186/s40104-017-0211-3.

Shen, S., S. Wang, Y. He, H. Hu, B. Yao, and Y. Zhang. 2020. Regulation of bone morphogenetic protein 4 on epithelial tissue. J. Cell Commun. Signal. https://doi.org/10.1007/s12079-019-00537-3.

Siqueira, L. G., and P. J. Hansen. 2016. Sex differences in response of the bovine embryo to colony-stimulating factor 2. Reproduction 152:645-654. https://doi.org/10.1530/REP-16-0336.

Sirisathien, S., H. J. Hernandez-Fonseca, P. Bosch, B. R. Hollet, J. D. Lott, and B. G. Brackett. 2003. Effect of leukemia inhibitory factor on bovine embryos produced in vitro under chemically defined conditions. Theriogenology 59:1751-1763. https://doi.org/10 .1016/S0093-691X(02)01258-X.

Soto-Heras, S., M. T. Paramio, and J. G. Thompson. 2019. Effect of pre-maturation with C-type natriuretic peptide and 3-isobutyl1-methylxanthine on cumulus-oocyte communication and oocyte developmental competence in cattle. Anim. Reprod. Sci. 202:4957. https://doi.org/10.1016/j.anireprosci.2019.01.007.

Sponchiado, M., N. S. Gomes, P. K. Fontes, T. Martins, M. Del Collado, A. A. Pastore, G. Pugliesi, M. F. G. Nogueira, and M. Binelli. 2017. Pre-hatching embryo-dependent and -independent programming of endometrial function in cattle. PLoS One 12:e0175954. https://doi.org/10.1371/journal.pone.0175954.

Tríbulo, P., L. Balzano-Nogueira, A. Conesa, L. G. Siqueira, and P. J. Hansen. 2019a. Changes in the uterine metabolome of the cow during the first 7 days after estrus. Mol. Reprod. Dev. 86:75-87. https://doi.org/10.1002/mrd.23082.

Tríbulo, P., G. Jumatayeva, K. Lehloenya, J. L. Moss, V. M. NegrónPérez, and P. J. Hansen. 2018a. Effects of sex on response of the bovine preimplantation embryo to insulin-like growth factor 1, activin A, and WNT7A. BMC Dev. Biol. 18:16. https://doi.org/10 .1186/s12861-018-0176-2.

Tribulo, P., B. C. D. S. Leão, K. C. Lehloenya, G. Z. Mingoti, and P. J. Hansen. 2017. Consequences of endogenous and exogenous WNT signaling for development of the preimplantation bovine embryo. Biol. Reprod. 96:1129-1141. https://doi.org/10.1093/biolre/ iox048.
Tríbulo, P., R. M. Rivera, M. S. Ortega-Obando, E. A. Jannaman, and P. J. Hansen. 2019b. Production and culture of the bovine embryo. Methods Mol. Biol. 2006:115-129. https://doi.org/10.1007/978-1 -4939-9566-0_8.

Tríbulo, P., L. G. B. Siqueira, L. J. Oliveira, T. Scheffler, and P. J. Hansen. 2018b. Identification of potential embryokines in the bovine reproductive tract. J. Dairy Sci. 101:690-704. https://doi .org/10.3168/jds.2017-13221.

Ware, C. B., M. C. Horowitz, B. R. Renshaw, J. S. Hunt, D. Liggitt, S. A. Koblar, B. C. Gliniak, H. McKenna, T. Papayannopoulou, B Thoma, L. Cheng, P. J. Donovan, J. J. Peschon, P. F. Bartlett, C. R. Willis, B. D. Wright, M. K. Carpenter, B. L. Davison, and D. P. Gearing. 1995. Targeted disruption of the low-affinity leukemia inhibitory factor receptor gene causes placental, skeletal, neural and metabolic defects and results in perinatal death. Development 121:1283-1299.

Williams, R. L., D. J. Hilton, S. Pease, T. A. Willson, C. L. Stewart, D. P. Gearing, E. F. Wagner, D. Metcalf, N. A. Nicola, and N. M. Gough. 1988. Myeloid leukaemia inhibitory factor maintains the developmental potential of embryonic stem cells. Nature 336:684687. https://doi.org/10.1038/336684a0.

Wooldridge, L. K., and A. D. Ealy. 2019. Interleukin-6 increases inner cell mass numbers in bovine embryos. BMC Dev. Biol. 19:2. https: //doi.org/10.1186/s12861-019-0182-z.

Wooldridge, L. K., S. E. Johnson, R. R. Cockrum, and A. D. Ealy. 2019. Interleukin-6 requires JAK to stimulate inner cell mass expansion in bovine embryos. Reproduction 158:303-312. https://doi .org/10.1530/REP-19-0286.

Xi, G., L. An, Z. Jia, K. Tan, J. Zhang, Z. Wang, C. Zhang, K. Miao, Z. Wu, and J. Tian. 2018. Natriuretic peptide receptor 2 (NPR2) localized in bovine oocyte underlies a unique mechanism for C-type natriuretic peptide (CNP)-induced meiotic arrest. Theriogenology 106:198-209. https://doi.org/10.1016/j.theriogenology 2017.09.003.

\section{ORCIDS}

Lei Sang $\bullet$ https://orcid.org/0000-0002-9652-7311

W. Ortiz @ https://orcid.org/0000-0002-7335-3961

Y. Xiao 구 https://orcid.org/0000-0002-5153-6839

E. Estrada-Cortes @ https://orcid.org/0000-0003-0226-9794

E. A. Jannaman @ https://orcid.org/0000-0003-2461-6793

P. J. Hansen (1) https://orcid.org/0000-0003-3061-9333 